\title{
技術 報告
}

\section{高温脱ガス用二重真空大型排気炉}

\author{
斉藤 芳男*.成島 勝也* $\cdot$ 佐藤 吉博*.久松 広美* \\ 松田 七美男 ${ }^{* *} \cdot$ 水野 元* . 福田 茂樹*. 竹内 保直*. 堀越 源一 ***
}

（受付 1990 年 4 月 13 日，掲載決定 1990 年 5 月 12 日）

The Vacuum Furnace for High Temperature

Bakeout of high power Vacuum Tubes

\begin{abstract}
Yoshio SAITO*, Katsuya NARUSHIMA*, Yoshihiro SATO*, Hiromi HISAMATSU* ${ }^{*}$ Namio MATUDA**, Hajime MIZUNO*, Shigeki FUKUDA*, Yasunao TAKEUCHI* and Gen'ichi HORIKOSHI***

* (National Laboratory for high Energy Physics, Tsukuba, Ibaraki, 305)

**(Faculty of Engineering, Tokyo Denki University, Kanda, Tokyo, 101)

***(Tsukuba Institute of Technology, Tsukuba, Ibaraki, 305)
\end{abstract}

(Received April 13, 1990, Accepted May 12, 1990)

\section{1.はじめに}

真空装置においてより低い圧力を得るためには，大き い活性化エネルギーを持つ吸着・吸蔵分子まで取除く必 要がある．現実的な時間制約内でこれを実現するために は，より高い温度でベーキングを行なえば良いことにな るが，その労力や費用は非常に増大する．多くの場合， ベーキングは $250^{\circ} \mathrm{C}$ 程度以下で行ならのが実用上の限度 であり,このため使用材料の表面処理やプリベーク脱ガ ス処理を行ない，ガス放出速度を更に下げる工夫をす る.

しかしながら，このよらな処理を行なった素材を用い ても，組立て後に高い温度 $\left(500 \sim 600^{\circ} \mathrm{C}\right)$ でベーキン グを行なわねばならない場合もある. 真空遮断器（スイ ッチチューブ）や，クライストロン及びジャイラトロン などのいわゆる電子管と呼ばれるものがこの例である.

これらは，製作後相当の排気速度をもつポンプを付帯さ せたままでは使用に際して不便であるし，又，ポンプの 保守や費用の問題も大きい，従って，バルブを持たない 封じ切り（チップオフ）管の構造となっており, 製造後

\footnotetext{
* 高エネルギー物理学研究所（采305 荻城県つくば市大穂1-1

** 東京電機大学工学部（干101 東京都千代田区神田錦町2-2）

*** 筑波技術短期大学（广305 茨城県つくば市天久保4-3）
}

の排気は殆んど期待できない（小型のイオンポンプを取 り付けることもあるが, 排気といらよりも, 内部圧力の モニターとして用いる程度である). 又, 電子管はその 材料として, ステンレス鋼, 無酸素銅, 絶縁用アルミナ セラミック等を用い, 製造工程が複雑で部品の再污染が 起きやすい．更に溶接だけでなく水素雾囲気中のろら付 箇所が多いため, 組立て後の段階で材料中に多量の水 素が溶解吸蔵されている. 電子源としてのカソードを持 つ電子管では, バリウム化合物による内部污染もカソー ド熱処理の際に発生する.これらのことから，電子管の 製作に於いては組立て後なるべく高い温度でベーキング を行ない, 污染を取除き, ガス放出速度を極力低下させ ておくことが必要不可欠となる.

金属材料の結晶粗大化やろら付け部分の信頼性等の問 題から，ベーキング温度は500〜 $600^{\circ} \mathrm{C} か ゙$ 選ばれるが, その際大気中でこれを行ならと外表面が酸化してしまっ たり，水蒸気の分解による水素の再溶解が起きる。そこ で容器 (真空管) 外側も低い圧力に保ってベーキングを 行なう事が必要となる。このための加熱炬が二重真空排 気炉と呼ばれる。

本報告では，大型クライストロン開発・試作のため に, 高エネルギー物理学研究所に於いて製作した大型二 重真空排気炉 ${ }^{1)}$ につて，基礎的な真空技術に関わる問 
題点を挙げながら紹介する.

\section{2. 大型二重真空排気炉}

加速器の高周波源として用いられるクライストロン は, より大きい出力が要請される現在その寸法は大型化 しつつある. 今回製作した真空炉2) はこのため有効内容 積を, 直径 $1.5 \mathrm{~m}$, 高さ $2.5 \mathrm{~m}$ とした. 図 1 に模式図を

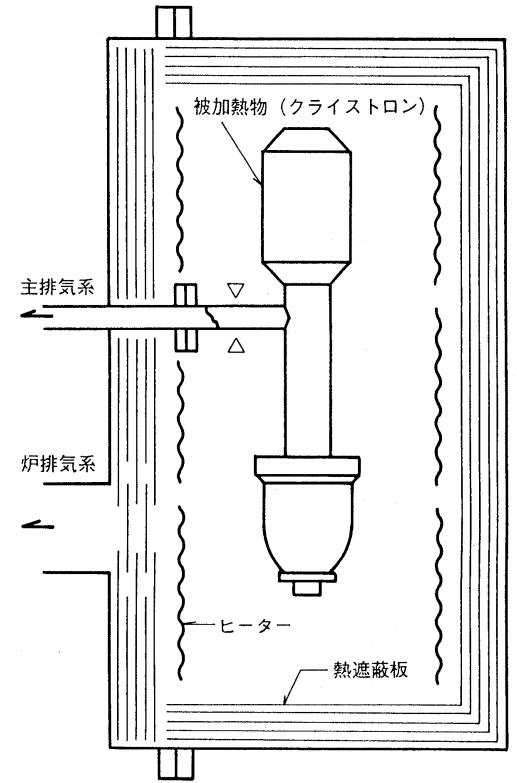

図 1 高温脱ガス用二重真空排気炉の模式図. $\triangle$ 印 は, 脱ガス後のチップオフを行なら部分（無 酸素銅パイプ).
示す. 又, クライストロンの大出力化に伴いその内部に 発生する電界強度も高くなり, 内部の残留ガスや表面污 染が原因となる放電も起こりやすくなる．このためクラ イストロンの加熱脱ガス工程も $550^{\circ} \mathrm{C} ， 150$ 時間以上の ものが必要となってくる．従ってクライストロンの排気 系には排気速度だけでなくスループット量の大きいポン プを使用せねばならない，表１に真空炉及び排気系の概 ねの仕様をまとめた，尚，この真空炉は，最初に述べた 被加熱物の外壁の酸化防止のために用いるだけでなく， 大型素材のプリベークにも使用できるよう，炉内圧力の 目標を $10^{-8}$ Torr（加熱時でも $10^{-6}$ Torr を超えない）と した.

\section{3. 真空炉開閉用大型フランジ}

真空炉内部にクライストロンを設置する際の作業性を 良くするため, 炉の開閉は図 2 に示すように回転式とし た.こうため, 昇降式のベルジャーと比べると, 真空シ ール部の長さが長くなり, 又, 自重でガスケット部をつ ぶせないのでクランプによるフランジの押えも必要とな る. 図 3 は, フランジの合わせ部分の概略図である. 直 径 $15 \mathrm{~mm}$ のネオプレンOリング（周長 $12 \mathrm{~m}$ ) を深さ $10.5 \mathrm{~mm}$ のアリ溝（炉の内側へはガス抜穴が切ってあ

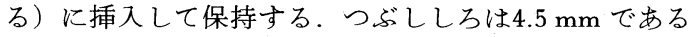
ので，まずフランジ単体（縦 $4.3 \mathrm{~m}$ ，横 $2.2 \mathrm{~m}$ ，幅 200 $\mathrm{mm}$ の額縁形で，厚さ50 mm）の平面性を，合わせ状態 で隙が $2 \mathrm{~mm}$ 以内におさまるように加工し，次にひずみ の発生に注意して炉本体に溶接した，完成した炉を設置 した後に，実際のフランジ面間距離を周囲18ケ所で測定 した．図4の a は炉に取付けた駆動輪によりフランジを

表 1 クライストロン脱ガス用二重真空大型排気炉の概略

\begin{tabular}{|c|c|}
\hline 大きさ & 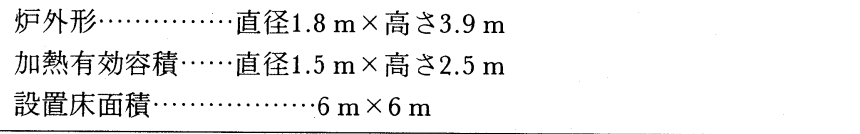 \\
\hline 炉 温 度 & $\begin{array}{l}\text { 常用 } 550^{\circ} \mathrm{C} \cdots \cdots\left(\text { 最高 } 700^{\circ} \mathrm{C}\right) \\
\text { 昇温速度 } \cdots 20 \mathrm{deg} / \mathrm{h} \sim 100 \mathrm{deg} / \mathrm{h} \text { 可変 (PID 制御) }\end{array}$ \\
\hline ヒ - タ & $\begin{array}{l}\text { ニクロムリボン }(\mathrm{NCH}-1) \text { 厚さ } 1.8 \mathrm{~mm} \times \text { 巾 } 13 \mathrm{~mm} \\
163 \mathrm{~m} \times 3 \text { 帯 }(3 \text { 相 } 200 \mathrm{~V})\end{array}$ \\
\hline $\begin{array}{l}\text { 絶縁碍子 } \\
\text { 熱遮蔽板 }\end{array}$ & $\begin{array}{l}91 \% \text { ア シナセラミック, 気孔率 } 0 \% \text {, 体積抵抗率 }\left(700^{\circ} \mathrm{C}\right) 10^{6} \Omega \cdot \mathrm{cm} \\
\text { SUS } 304,0.5 \mathrm{t} \times 6 \text { 層 }\end{array}$ \\
\hline $\begin{array}{l}\text { 炉排気系 } \\
\text { 主 気 系 }\end{array}$ & 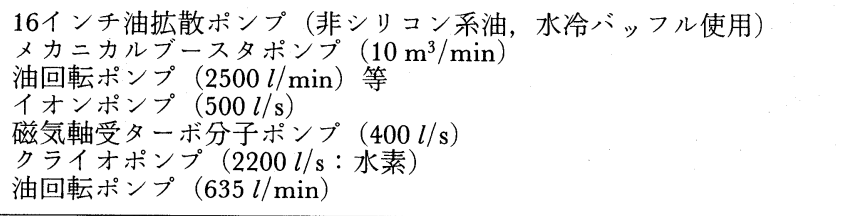 \\
\hline
\end{tabular}




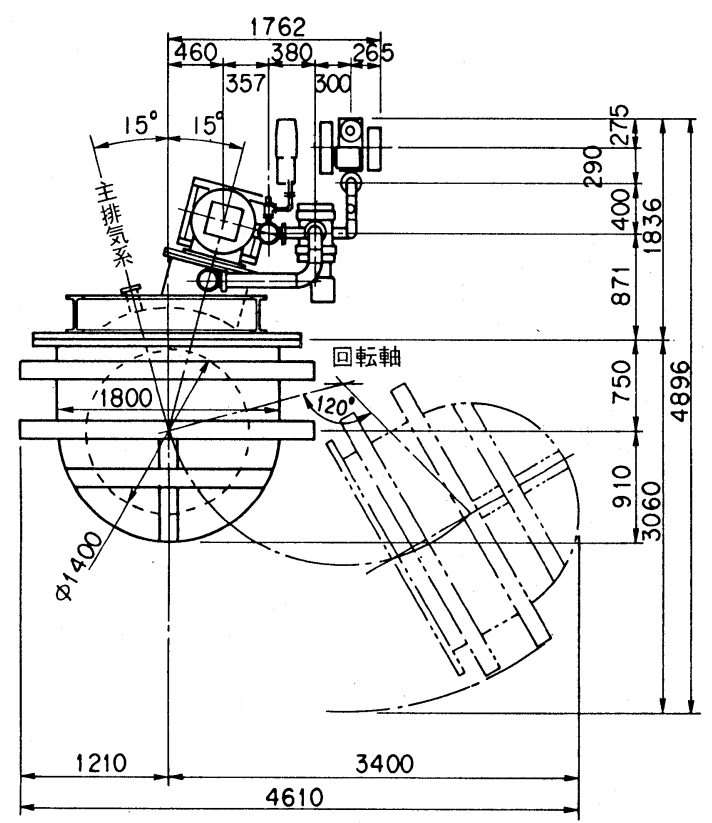

図 2 製作した炉の開閉の様子. 上から見た状態.

接近させた時の様子である.フランジの一部は接触して いるが他の部分（下方）は $4.5 \mathrm{~mm}$ 以上離れている. 回 転軸の取付部分の微調整だけではこれ以上の精度を求め るのは困難であった。 このままで排気を開始してしまう と, 大気圧でフランジが押されて全周が密着するまでに 隙間からホコリ等を吸入してしま5。bは，クランプ (エアシリンダ駆動, 回転軸側 $125 \phi 3$ 個, 反対側 $100 \phi 5$ 個）によりフランジを押えつけた状態の様子であり，こ の場合は充分密着していることがわかる. c は更に炉の 排気を行ない内部を真空にした時である. 大気圧により 炉全体が押し付けられ，より密着性が良くなる（フラン ジ上下部）とともに変形も多少見られる（フランジ左右 部分). この測定はフランジ最外周（シール面から120 $\mathrm{mm}$ 外側）で行なっているので，観察された変形はの リング当り面を支点としたフランジのソリと考えられ る. 実際, リークは発生しなかった. 又, 数回の炉の加 熱運動を行なった後も, (1)〜3)の状態は再現したので, 熱ひずみのないフランジである事が確認された。これは 炉内の熱遮蔽板（6枚）の効果により炉壁そのものの温 度上昇が低く押えられた（炉の外壁は水冷状態で $40^{\circ} \sim$ $50^{\circ} \mathrm{C}$ 温度上昇）ためと考えられる。

\section{4. 炉内の絶緑碍子}

真空炉容器内壁, 熱遮蔽板, ヒータ, 絶縁碍子の総表 面積は約 $400 \mathrm{~m}^{2}$ (炉の容積は約 $11 \mathrm{~m}^{3}$ ) で, このうち

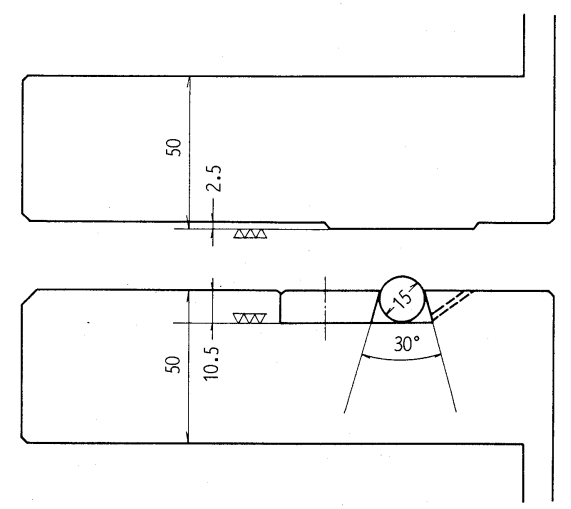

図 3 炉フランジの真空シール部. Oリングは $15 \phi$, ガス抜穴は $2 \phi$.

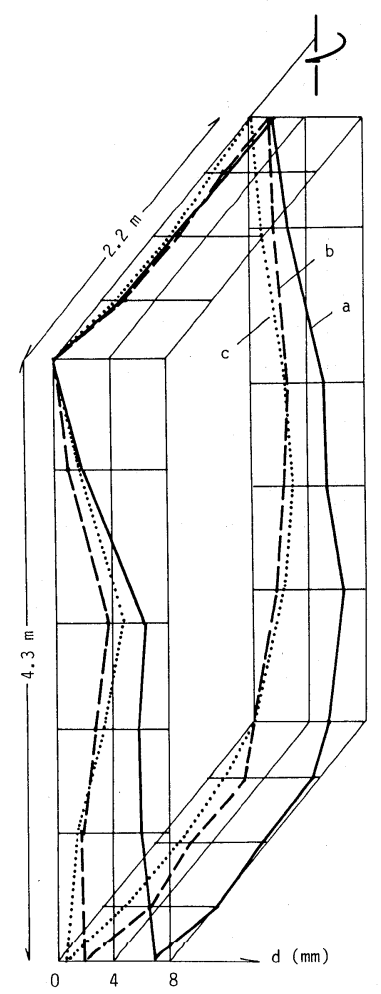

図 4 炉フランジのフランジ面間距離 $(d)$ の測定 結果（周囲18か所を測定し, そのらちの最 小值を差引いた値) . $\mathrm{a}$ ：炉の駆動輪のみに よる接近. b : クランプによる圧着（炉内は 大気圧). $\mathrm{c}$ ：炉内を排気 $\left(\sim 10^{-6}\right.$ Torr $)$.

$350 \mathrm{~m}^{2}$ 近くは熱遮蔽板によるものであり, 絶縁碍子 （2000組）の表面積は $20 \mathrm{~m}^{2}$ 程度である。しかし，焼結 体である絶縁碍子はその気孔率により真の表面積が大き く変わり, 熱遮蔽板の表面積よりもはるかに大きくなっ 
てしまら事も予想される．ヒータ近傍で使用され温度も 高くなるので, この場合には絶縁碍子からのガス放出量 が支配的となり, 到達圧力に影響を与えるだけでなく加 熱開始初期には放電の発生も誘らことが考えられる. 本 装置では耐熱性だけでなくこの点も考慮して，多少高価 であるが緻密質（気孔率 $0 \%$ ）のアルミナセラミック3） を絶縁碍子として使用した．図 5 は, 炉を大気曝露した 後に再排気した際の, 圧力変化の様子である（1回目は 製作直後で加熱履歴は受けていない). 回数とともに系 が枯れていき, $700^{\circ} \mathrm{C}$ の加熱運転の後は注ぼ安定して3.5 時間で $10^{-6}$ Torr，60時間後に $10^{-8}$ Torr に到達するよう になった．排気開始10時間後の圧力から炉内（加熱して いない）のガス放出速度を見積る（総面積 $400 \mathrm{~m}^{2}$ とし， 材料により差がないとする）と $10^{-10} \sim 10^{-11}$ Torr $\cdot l / \mathrm{cm}^{2}$ ·s となる.これは一般的なステンレス鋼での経験值と 同程度であり, 絶縁碍子からの全ガス放出量が支配的で はないことを示していると考えられ, 緻密性アルミナ七 ラミックの使用は効果があったと思われる.

なお炉の種算加熱時間が300時間程度経過した時, ヒ 一タに地落（ヒータの対地抵抗が $2 \mathrm{k} \Omega$ 以下となった） が発生した。 これは絶縁碍子表面に付着したよごれによ るもので, ヒータの黒かわ（Ni や Cr の酸化被膜で圧力 の高い雲囲気中で使用する場合は保護膜となる）が加熱 により脱離したものと判断された。 ニクロムヒータ表面 をビーズブラストにより清浄化し, 碍子は空気中で再加 熱することにより，以後安定した加熱運転が可能となっ ている。

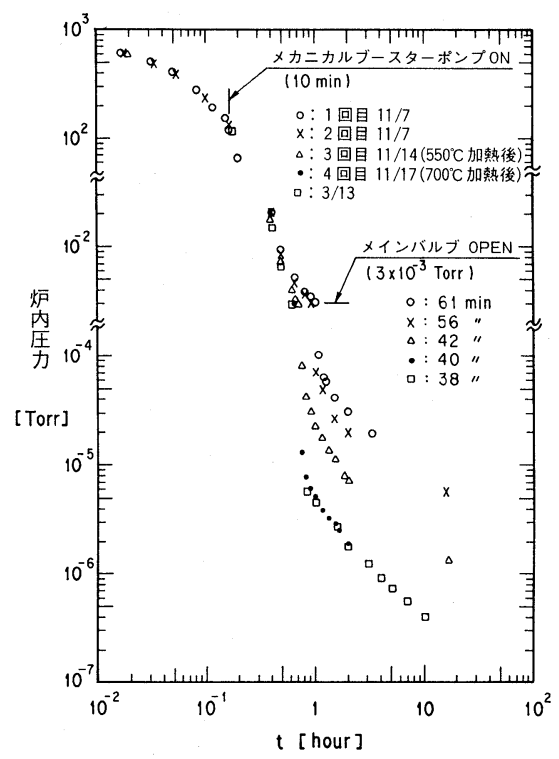

図 5 大気曝露後の, 炉の再排気初期特性.

\section{5. 炉内に使用するフランジ}

被脱ガス体（クライストロン）そのものが持つ組立用 フランジ，及び，排気管接続フランジは， $550^{\circ} \mathrm{C} て ゙ 150$ 時間の加熱履歴に耐えるものでなければならない，ステ ップ型フランジ4) は高温加熱に対し実積はあるが，オス ・メスを持つ非対称形で汎用性が少ないので，今回はコ ンフラットフランジを用いた。現在までにリーク発生が しばしば起きたが，その殆んどは，フランジとガスケッ トの「寸法精度」，及びそれらの「硬さ」，締め付けねじ の「摩擦」の 3 つ問題に鹵着されると解釈された，以 下に実際に起きた例を具体的に述べる。

ガスケット外周端面に大きい「だれ（打抜ガスケット に多く見られる)」を持つもの，又，フランジ側のガス ケット受溝の直径が小さくガスケットを入れにくいもの などを組み合わせた場合は加熱履歴によりリークが発生 しやすい，これは，フランジ締め付けの際にエッジがガ スケットに食い込んでもガスケット外周端面がフランジ の溝側面に均一に当たらず，キップチャーシールにとっ て必要な加工硬化が部分的にしか達成されなかったた め5) と考学られる。ガスケットの硬度に関しては， $H_{\mathrm{V}}$ (ビッカース硬度）～80を持つ市販の無酸素銅ガスケッ トを使用した際，加熱後リークしてしまう事が多く，エ ッジの食い込み不足やフランジのゆるみが認められた. これは，1つには後述するねじ（脱脂洗浄したもの）の 摩擦が原因で，つまり通常のトルクでねじを回転させて も充分な締め付け力が得られず，エッジの食い込みが少 ないためガスケットの加工硬化がそれ程進まなかったか らといえる.これに対して軟らかい無酸素銅ガスケット を用いれば，同じ締め付け力でも深い食い込みが得ら れ, 即ち加工硬化後の弾性応力の大きさは同じでもそれ に到るまでの塑性変形量は大きいので，加熱による弾性 応力の低下は少ない事が期待される．実際，焼鈍したガ スケット $\left(H_{\mathrm{V}} \sim 40\right)$ では，リーク事故は少ない傾向に あった。な拈，フランジはSUS 316 材の方がSUS 304 材で製作したものよりリーク発生は少なく，高温での機 械的強度の大きい事を示していると考えられる。

炉内で使用するボルトナットには，グリースや $\mathrm{MoS}_{2}$ 塗布材等通常の潤滑剤は污染や粉塵発生の原因となり使 用できない。図 6 は，ボルトに加えた回転トルクとそれ により生ずる軸力 (6) 測定7) した結果である．脱脂洗浄 したボルト・ナットの組合せでは，得られる軸力は潤滑 剂塗布の場合の 3 分の 1 程度でしかなく, 又, ねじ部の 表面仕上げ状態によると思われるバラッキも見られた。 更に測定を繰返すにつれて軸力の低下が観察される事が 多く, 摩耗が進行して摩擦面の状態が変化したと考えら 

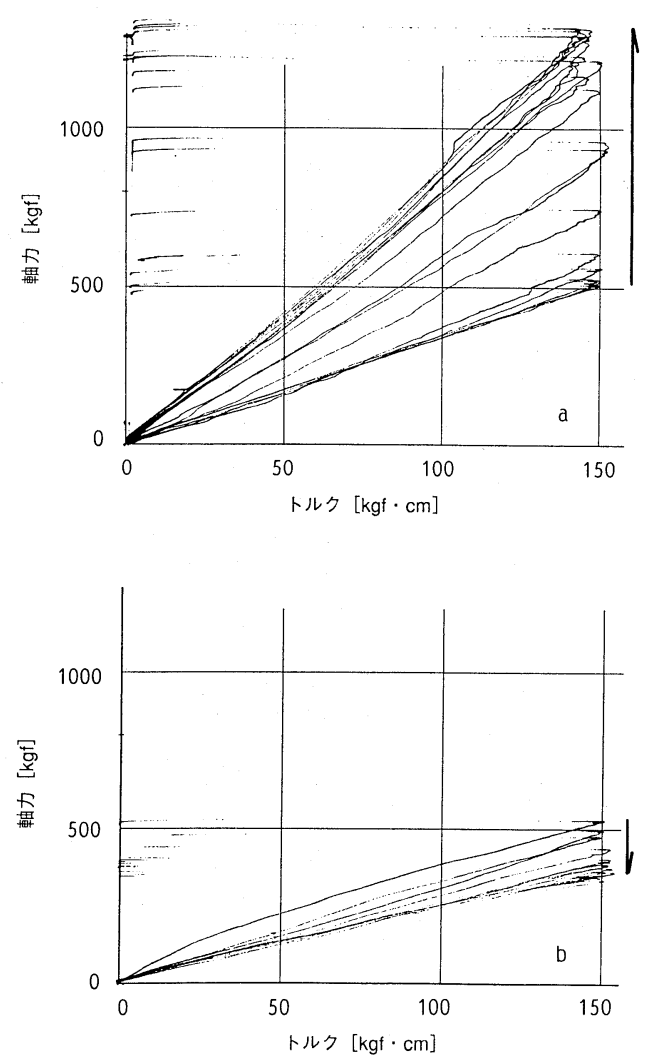

図 6 ボルト・ナットの軸力測定結果. SUS 316 ボ ルト・ナット $(\mathrm{M} 8, p=1.25)$ を使用. $\mathrm{a}$ : 二 硫化モリブデン潤滑剤塗布の場合. 回転を 繰り返すうちに軸力が増加するのは, 潤滑 剤がねじ表面になじんでいくためと思われ る. b : 脱脂洗浄した場合. 回転の繰りかえ しにより摩耗が進み摩擦係数が増加したと 考觉られる。

れる. 炉中で使用した後のねじの解除の際には, 加熱に よるやきつきも起きた。これを防止するために金属接触 面の拡散障壁として TiN 薄膜をコーティングする事が ある. 実際に $2 \mu \mathrm{m}$ の TiN 膜（ホロカソード放電成膜） をボルトに施したところ，やきつきは少なくなった。
又, トルク・軸力測定結果から, ねじの回転に伴なう軸 力低下も起こらず常に一定の締め付けが可能である事が わかった。しかしながら得られる軸力はやはり潤滑剂使 用時の 3 分の 1 程度でしかなかった. TiN コーティン グは，ねじの焼き付きや摩耗を減少させる効果 ${ }^{8)}$ はある が，その摩擦係数を低減させてはいないと言える

\section{6. おわりに}

製作した高温脱ガス用二重真空排気炉で，実際にクラ イストロンを排気した。 $550^{\circ} \mathrm{C}$ の加熱状態で全圧は $10^{-7}$ Torr から100時間後には1.5桁低下し10-9 Torr 台となっ た. その時点で加熱を停止し $200^{\circ} \mathrm{C}$ （加熱停止から約 30 時間後）では $10^{-10}$ Torr 台に到達した. 加熱時の残留ガ スは主として水素であり全圧と同様の減少を示した．従 ってクライストロン構成材料の吸蔵ガスは水素が主であ ることが確かめられ, 又, その脱ガスにはこのよらな高 温二重真空炉による長時間の排気が有効であると結論で きる.

実際の加熱に際しては, 炉内でのフランジ接続に充分 注意を払わねばならない事がわかった．特にコンフラッ トフランジに於いて理想的なキャップチャーを得るため には, フランジやガスケットの寸法精度及び硬さの管理 が重要であり, 更にボルト・ナット間の摩擦に関しても 考慮しなおす事が必要であろら。

\section{[文献〕}

1）成島勝也他：Proceedings of the 7th Meeting on Ultra High Vacuum Techniques for Accelerators and Storage Rings, KEK Report 82-2, (1989) 139.

2）製造はタイホー工業及び徳田製作所.

3） $\mathrm{KP}-91$, 日本特殊陶業.

4) 斉藤芳男 : 真空, 32 (1989) 625.

5）永井康睦他：真空, 33 (1990) 21.

6)山本晃：“ねじ締結の理論と計算”, 養賢堂 (1970).

7）久保富夫他：真空, 25 (1982) 50.

8）田村繁治他：第30回真空に関する連合講演会講演予 稿集（1989）152. 